\title{
As bibliotecas dos jesuítas: uma visão a partir da obra de Serafim Leite
}

\section{Luiz Antonio Gonçalves da Silva \\ Doutor em ciência da informação pela Universidade Complutense de Madrid, Espanha; Tecnologista do Instituto Brasileiro de Informação em Ciência e Tecnologia (Ibict)}

As primeiras bibliotecas do Brasil foram as pertencentes às ordens religiosas, entre as quais a Companhia de Jesus. Pouco se sabe sobre elas. As bibliotecas jesuíticas são as de que se tem mais conhecimento, em razão da obra História da Companhia de Jesus no Brasil, de Serafim Leite. O presente artigo tem o objetivo de revisar e reunir as informações que aparecem ao longo do trabalho, para oferecer uma visão de conjunto do tema.

Palavras-chave: Bibliotecas; História; Jesuítas; Período colonial.

\section{The jesuits's libraries: a view based on Serafim Leite's work}

The first libraries in Brazil belonged to religious orders, such as the Companhia de Jesus (Company of Jesus/Society of Jesus). Little is known about them except for the jesuitic libraries which are the best known of them, due to the work História da Companhia de Jesus no Brasil by Serafim Leite. The present article aims to review and collect the information contained in that work, and thus offer an overview of the theme.

Keywords: Colonial period; Libraries; History; Jesuits.

Recebido em 30.12.2008 Aceito em 18.06.2008

\section{Introdução}

As primeiras bibliotecas do Brasil foram as pertencentes às ordens religiosas que aqui se instalaram a partir da metade do século XVI, como 
a Companhia de Jesus, a Ordem dos Frades Menores - os Franciscanos, a Ordem de São Bento, a Ordem Carmelita e, posteriormente, a Congregação do Oratório ${ }^{1}$. Pouco se sabe ainda hoje sobre essas bibliotecas. Faltam pesquisas ${ }^{2}$. As bibliotecas jesuíticas são as de que se tem mais conhecimento, em razão do trabalho História da Companhia de Jesus no Brasil, de autoria do padre Serafim Leite, S. J. (1880- 1969) ${ }^{3}$. Trata-se de uma obra abrangente sobre a atuação da ordem no país. Consta de 10 volumes publicados no período de 1938 a 1950. Foi reeditada de forma monumental em 2004, com o patrocínio da Petrobras, edição que foi utilizada para a elaboração deste artigo ${ }^{4}$.

$\mathrm{O}$ autor baseou seu trabalho em consultas a fontes primárias e secundárias. O Arquivo Geral da Companhia de Jesus (Archivum Societatis Iesu Romanum), em Roma, foi a mais importante fonte. As pesquisas ali realizadas constituem o fundo principal da obra. Foram também consultados arquivos e bibliotecas em Portugal, Itália, Espanha, França, Bélgica e Holanda. No Brasil, foram percorridos vários arquivos, quando o autor pôde verificar e lamentar o descuido e a destruição em relação aos acervos (t. I, p. XXXI). Foi também utilizada ampla bibliografia de escritores dos séculos XVI, XVII e XVIII e de autores da historiografia brasileira.

No que se refere aos livros e bibliotecas - o autor usa o termo livraria, que era o usual na época -, são encontradas informações ao longo de toda a obra. O presente artigo tem o objetivo de revisar e reunir essas informações para oferecer uma visão de conjunto do tema.

\section{A Companhia de Jesus}

Em 1539, o espanhol de origem basca Inácio de Loiola (1491-1556) e companheiros fundaram, na Europa, a Companhia de Jesus, aprovada no ano seguinte pelo papa Paulo III. A ordem religiosa, cujos membros passaram a ser conhecidos como jesuítas ou inacinanos, expandiu-se rapidamente no continente, e logo estava partindo para se instalar nas terras recém-descobertas pelos europeus, como a Índia, China e Japão e regiões da África e da América portuguesa e espanhola.

\section{A Companhia no Brasil (1549-1759)}

Os jesuítas chegaram ao Brasil em 1549 junto com o segundo governador-geral Tomé de Souza, 10 anos após a fundação da ordem. $O$ grupo, composto de seis religiosos, era dirigido pelo padre Manoel da Nóbrega (1517-1570). A presença da ordem no país se estendeu por dois

\footnotetext{
Considera-se, neste trabalho, como bibliotecas, aquelas pertencentes a instituições, embora seja conhecida a posse de livros por particulares como prelados e autoridades no período colonial.

2 Borba de Moraes comenta a falta de informação sobre essas bibliotecas. Cf. MORAES, R. B. Posfácio. In:__ Livros e bibliotecas no Brasil colonial. 2. ed. Brasília: Briquet de Lemos, 2006. p. 183.

3 Serafim Leite nasceu em Portugal nas proximidades do Porto. Ingressou na Companhia de Jesus em 1914. Logo dedicou-se a escrever a história da ordem no Brasil, tarefa que levou ao longo de sua vida.

4 LEITE, S. História da Companhia de Jesus no Brasil. São Paulo: Loyola, 2004. 10 v. Há também uma reedição fac-similar publicada pela Itatiaia Editora em 2006.
} 
séculos e compreendeu a Província do Brasil e a Vice-Província do Maranhão e Pará, ambas dependentes da Assistência de Portugal. Em 1759, os jesuítas foram expulsos do país e de todos os territórios portugueses por ordem do Marques de Pombal.

Além de se ocupar com a assistência religiosa aos colonos e com a catequese dos índios, os padres se dedicaram de modo especial à educação e ensino de crianças e jovens nas chamadas aulas de ler, escrever e contar. Para tanto, construíram igrejas, colégios, residências e seminários, e instalaram missões. Destacavam-se os colégios, 19 em meados do século XVIII, que funcionavam como verdadeiros centros culturais da época, com atividades literárias, musicais e teatrais.

\section{A formação das livrarias}

Uma vez iniciada uma obra, os padres começavam a providenciar os meios para o exercício de suas atividades. Entre eles estavam os livros. Constituíam a base para a ação dos jesuítas, e a sua falta prejudicava as atividades da ordem na catequese dos índios, assistência religiosa, ensino e educação dos colonos. E assim procuravam instalar livrarias em todos os seus estabelecimentos, desde os mais importantes, situados nas sedes das províncias, até os mais modestos nas distantes aldeias. Referindo-se às casas no norte do Brasil, Serafim Leite afirma: "Não havia aldeia, por mais recuada que fosse na profundeza dos sertões e rios, que a não iluminasse ao menos uma estante de livros" (2004, t. IV, p. 113).

As principais livrarias eram as dos colégios, que tiveram seu apogeu no século XVII e na primeira metade do XVIII. Essas, por sua vez, abasteciam as residências que delas dependiam, como aconteceu na Bahia. Para haver maior controle, foi determinado em 1587 que, quando morresse um padre em alguma residência, fossem inventariados os livros que estivessem em seu poder. Ficava ao critério do Provincial decidir se os mesmos deveriam permanecer na residência ou ser recolhidos para a livraria do colégio (LEITE, 2004, t. II, p. 390).

Nos colégios existiam farmácias, conhecidas como boticas, que atendiam à população, como na Bahia, Rio de Janeiro, Pará e Maranhão. Algumas chegaram a ter livrarias próprias com livros relacionados à medicina. A botica do Colégio do Maranhão possuía "30 tomos de medicina e botica" (LEITE, 2004, t. IV, p. 113). Foram as antecessoras das bibliotecas de saúde.

Quando os padres partiam de alguma capitania para fundar uma missão em outro local, levavam os livros necessários. Assim aconteceu com a expedição de 1586, que partiu da Bahia com o propósito de fundar uma missão no Paraguai. Levava consigo "muitos livros" (LEITE, 2004, t. II, p. 390). Quando os navios chegaram à entrada do Rio da Prata, foram atacados por corsários ingleses chefiados por Robert Withrington, que saquearam todos os objetos a bordo, incluindo os livros (LEITE, 2004, t. II, p. 121).

A inexistência de livros em determinado local era considerada um sinal de carência de meios para a ação dos jesuítas. Um exemplo disso foi 
a Confraria dos Meninos de Jesus, no Espírito Santo, que atendia a meninos mamelucos e índios, e foi visitada em 1552 por Nóbrega, que assim lamentou: "As condições deste colégio eram precárias. [...] Toda a biblioteca [...] constava de um livro, a Vitae Christi" (LEITE, 2004, t. I, p. 79) $)^{5}$.

Em contrapartida, uma boa coleção era sinal de prestígio do colégio que a possuía e o credenciava para a criação de cursos. Em carta de 21 de março de 1661, na qual solicitava ao superior-geral a instalação de estudos no Maranhão, o padre Antonio Vieira (1608-1697) argumentava que o colégio possuía uma boa biblioteca para servir de base ao curso pleiteado com a afirmação: "Livraria temos muito boa" (LEITE, 2004, t. IV, p. 113).

\section{A criação dos acervos}

\section{Livros trazidos pelos padres}

Os primeiros livros foram trazidos pelos próprios jesuítas em sua bagagem. O núcleo do Colégio da Bahia, a mais importante de todas as livrarias e iniciada em 1549, foram os livros trazidos por Nóbrega (LEITE, 2004, t. V, p. 216). A do Colégio do Maranhão recebeu, no seu início, livros trazidos de Portugal pelo padre Vieira (LEITE, 2004, t. IV, p. 113).

Assim, a chegada dos padres era uma oportunidade para a entrada de livros. Um fato ilustrativo, embora frustrado, foi o ocorrido com o padre Fernão Cardim (c.1549-1625). Chegou ao Brasil em 1583 e ocupou diversos cargos de direção nos colégios da Bahia e do Rio de Janeiro ${ }^{6}$. De retorno de uma viagem a Roma, para onde foi como Procurador, o navio em que viajava foi capturado, ainda nas costas portuguesas, por corsários ingleses, comandados por Sir John Gilbert, no dia 25 de setembro de 1601. Os corsários se apoderaram de todos os objetos dos viajantes, inclusive os "muitos livros" da bagagem de Cardim. Em correspondência, o padre lamenta que "seus próprios manuscritos em português e latim, vidas de Cristo e comentários teológicos" tenham ficado nas mãos do pirata (LEITE, 2004, t. VII, p. 3). Libertado, Cardim embarcou para o Brasil em 1604. Não se sabe se trouxe consigo novos livros.

\section{As remessas da Europa}

Os livros eram também enviados da Europa pelos superiores e até pelo rei de Portugal, muitas vezes em atendimento a pedidos dos padres. Para os alunos do Colégio dos Meninos de Jesus, a primeira instituição de ensino dos jesuítas no Brasil, fundada por Nóbrega em Salvador, D. João III enviava livros e outros bens (LEITE, 2004, t. I, p. 16). Nos primeiros anos, as solicitações foram freqüentes. Necessitava-se de livros para

5 A obra poderia ser a Meditationes vitae Christi, cuja autoria é atribuída a São Boaventura (1221-1274), de grande popularidade na época.

6 Trata-se do autor da famosa obra Tratados da terra e gentes do Brasil, manuscrito do século XVI publicado em 1925. 
auxiliar as tarefas de catequese e de ensino. São vários os registros desses pedidos.

Logo após sua chegada, o padre Manuel da Nóbrega pediu livros, e assim argumentava: "Por que nos fazem muita míngua para as dúvidas que cá há, que todas se perguntam a mim" (LEITE, 2004, t. II, p. 389). Nóbrega certamente estava se referindo às questões que eram freqüentemente dirigidas não só a ele como aos demais companheiros, únicas fontes de consulta existentes na época. Também para os estudos que se seguiram ao Colégio dos Meninos de Jesus foram solicitados livros, destinados às aulas de latim (LEITE, 2004, t. I, p. 19). Em carta de 6 de janeiro de 1550, Nóbrega acusa 0 recebimento de duas caixas de livros, entre outros objetos (LEITE, 2004, t. II, p. 389). Em 1555, o padre Luiz da Grã, segundo provincial do Brasil, solicita livros de texto para os alunos principiantes e adiantados do Colégio da Bahia (LEITE, 2004, t. II, p. 390). O padre João Vicente Yate, que trabalhou na Bahia, Pernambuco e Rio de Janeiro, pedia, em 1593, obras em inglês, latim e espanhol (LEITE, 2004, t. II, V, p. 390). O irmão Pero Correia foi um dos primeiros a trabalhar diretamente com os índios e a aprender a língua nativa. Mandava vir expressamente livros da Europa para ajudar no seu trabalho de catequese em São Vicente (LEITE, 2004, t. II, p. 391). Em 1553, o mesmo irmão pedia livros em "linguagem", isto é, livros em português, já que desconhecia o latim, sugerindo que fossem procurados em Lisboa ou Sevilha (LEITE, 2004, t. II, p. 390).

A falta de livros nesses primeiros tempos fazia com que os padres providenciassem textos para as escolas. O padre José de Anchieta, por exemplo, ao começar as atividades do Colégio de São Paulo de Piratininga, escreveu apontamentos que foram distribuídos aos alunos (LEITE, 2004, t. II, p. 390). Posteriormente, foi prática nos colégios a elaboração de cartapácios, espécie de apontamentos ou apostilas que eram distribuídos gratuitamente aos estudantes (LEITE, 2004, t. IV, p. 113).

\section{As compras}

Outra forma usada para a ampliação dos livros foi a compra, que começou a ser realizada quando os colégios já estavam estabelecidos e auferiam rendas. Há registros de aquisições efetuadas pelos próprios padres provinciais. O padre Marçal Beliarte, provincial de 1587 a 1594, empregou a quantia de $15 \$ 000$ réis para a compra de livros, e enviou para a Europa uma partida de âmbar cuja venda rendeu $40 \$ 000$ e foi utilizada para a compra de livros (LEITE, 2004, t. II, V, p. 389) ${ }^{7}$. Para evitar que o interesse pelos estudos não diminuísse, e para animar as

O âmbar, mais precisamente o âmbar cinza, âmbar pardo, âmbar gris ou âmbar de baleia, é um subproduto da baleia, principalmente da espécie cachalote, que foi explorado pela indústria baleeira no Brasil no período colonial. Foi referido pela primeira vez na obra de Pero de Magalhães Gândavo História da Província de Santa Cruz (1676). 
atividades culturais, o padre Pero Rodrigues, que governou a província de 1594 a 1603, mandou vir "muitos e muitos livros" para o Colégio da Bahia (LEITE, 2004, t. II, p. 390).

Compravam-se também livros de pessoas que estavam de volta a Portugal após terem exercido funções na colônia. Era preferível vendê-los a pagar o frete de retorno. Em 1720, no Pará, foram adquiridos mais de 100 volumes, por $600 \$ 000$ réis, do ouvidor-geral, que estava de retorno à Europa (LEITE, 2004, t. IV, p. 113). Também no Pará há registro de envio de dinheiro ao procurador da Companhia em Lisboa para a compra de livros necessários (LEITE, 2004, t. IV, p. 113).

Os recursos destinados à aquisição de livros eram em parte oriundos dos rendimentos auferidos pelos colégios. Nos Colégios do Maranhão e Pará, cujas boticas vendiam medicamentos para a população rica, foi determinado, em 1732, que a renda obtida fosse empregada em parte na aquisição de livros (LEITE, 2004, t. IV, p. 113). Serafim Leite considera que os livros adquiridos com essa renda eram destinados não só às próprias boticas, mas também à livraria dos colégios (LEITE, 2004, t. IV, p. 113). Outra renda empregada para o mesmo fim foi a proveniente da exploração de gêneros agrícolas, como aconteceu no Maranhão, com a venda de cacau e cravo (LEITE, 2004, t. IV, p. 113).

Alguns padres recebiam recursos para a compra de livros de seu interesse, principalmente aqueles que se dedicavam aos estudos. Em 1643, no Colégio do Rio de Janeiro, há o registro de padres que "por amor a seus estudos privados tinham cem cruzados de livros" (LEITE, 2004, t. VI, p. 425).

\section{As doações}

As livrarias também foram ampliadas com doações de particulares. Vários são os registros. O Colégio da Bahia recebeu a livraria do bispo D. Pedro Leitão, que "era mui boa" (LEITE, 2004, t. II, p. 390). O Colégio do Rio de Janeiro registrou a doação da biblioteca do padre Bartolomeu Simões Pereira, composta de livros de direito civil e canônico (LEITE, 2004 , t. VI, p. 425). O Colégio do Recife anotou, em 1717, a entrada de vários volumes doados por "um homem nobre e erudito"(LEITE, 2004, t. V, p. 352).

\section{Ordenação e conservação dos livros}

A ordenação de livros, no início, visava a melhor controlar os acervos em formação. Assim aconteceu no Colégio da Bahia em 1589. Temendo-se a dispersão por empréstimos ou roubo, foi determinado que todos os livros fossem numerados em ordem seqüencial e etiquetados na lombada. Assim poderia haver melhor controle (LEITE, 2004, t. II, p. 390).

Houve também organização por assunto. No Pará, as estantes contavam com um local apropriado talhado na sua parte superior para a colocação de etiquetas com a indicação dos conteúdos das mesmas 
(LEITE, 2004, t. IV, p. 113). A livraria do Colégio da Bahia chegou a ter um catálogo de matérias e de autores organizado pelo bibliotecário Antonio da Costa por volta de 1694. O documento não foi localizado por Leite (LEITE, 2004, t. V, p. 216). Provavelmente é dos nossos primeiros trabalhos de catalogação e classificação, ainda por conhecer.

A conservação dos acervos também mereceu a atenção dos padres, por meio da encadernação e combate aos insetos. Quando os jesuítas começaram as suas instalações, mandavam buscar, na Europa, religiosos que soubessem exercer algum ofício. Eram necessários para atender às diversas necessidades de manutenção das casas. Entre eles, existiam os relacionados com a fabricação de artefatos de sola e couro, como curtição, confecção de calçados e encadernação (LEITE, 2004, t. IV, p. 64). São encontrados diversos colégios que possuíam livros encadernados e oficinas de encadernação próprias.

O Inventário, de 1760, da Casa dos Exercícios e Religiosa Recreação de Nossa Senhora Madre de Deus do Maranhão informa que quase todos os 1.000 volumes de sua livraria estavam encadernados (LEITE, 2004, t. III, p. 602). A livraria do Colégio Santo Alexandre, em Belém, possuía sua própria oficina de encadernação (LEITE, 2004, t. III, p. 519). A do Colégio da Bahia dispunha de um "hábil" encadernador (LEITE, 2004, t. V, p. 216).

O combate a cupins e outros insetos foi também preocupação. Muitas destas pragas eram desconhecidas dos europeus, que ignoravam a ação que poderiam exercer sobre o papel. Quando a livraria do Colégio do Rio de janeiro foi restaurada, no começo do século XVIII, foi posto em prática um programa de conservação, contra os estragos de cupim e traça (LEITE, 2004, t. VI, p. 425).

\section{As instalações e o mobiliário}

Principalmente nos colégios mais importantes, as livrarias estavam em locais destacados. Algumas possuíam instalações suntuosas, como as do Colégio da Bahia, únicas que foram conservadas. Trata-se de amplo salão com teto pintado e uma entrada azulejada com alegorias ao saber, que são considerados um dos belos exemplos da arte colonial, campo onde os jesuítas deixaram também relevantes contribuições. As do colégio do Pará e do Rio de Janeiro também deviam ter instalações importantes, a julgar pelas descrições encontradas. As do primeiro podem ser localizadas no edifício ainda existente em Belém. As do segundo desapareceram junto com a demolição do conjunto do colégio quando o Morro do Castelo foi arrasado em 1921.

No mobiliário, destacavam-se as estanterias. Algumas foram fabricadas com esmero, utilizando-se madeiras nobres. As atividades de carpintaria eram um dos ofícios mais importantes dos Colégios. Assim foi no Colégio do Rio de Janeiro. A livraria, restaurada no início do século XVIII, recebeu estantes novas feitas de jacarandá e vinhático. Em carta datada de 1721, o reitor Manuel Dias informa que elas "[não foram] lavradas de qualquer modo, mas com tal primor que no dizer dos que a 
viam e admiravam, assim deviam ficar, nuas na arte de entalhe e polimento, sem mais pintura nem dourados, por belos que fossem" (LEITE, 2004, t. VI, p. 425). São também referidas as estantes apropriadas dos colégios do Pará (LEITE, 2004, t. III, p. 519) e Maranhão (LEITE, 2004, t. IV, p. 113).

\section{As tipografias}

Serafim Leite informa a existência de atividades tipográficas nos colégios $^{8}$. Esta informação decorre da atividade de tipógrafo exercida por dois jesuítas. No Colégio do Rio de Janeiro, consta um que chegou a produzir "400 livros destinados ao uso privado da casa e dos padres" ( $t$. VI, p.425). Na Bahia, consta outro, denominado impressor. Ambos foram também encadernadores e bibliotecários. O registro destas atividades leva a levantar a possibilidade da existência, nos colégios citados, de atividade tipográfica, que poderia ter produzido pequenos impressos (LEITE, 2004, t. $V$, p. 216). Como também houve encadernação em alguns colégios, pode-se supor que houve a utilização de tipos, pelo menos para a confecção dos títulos nas lombadas e capas dos exemplares encadernados.

\section{Usuários, empréstimos, regulamentos e censura}

As livrarias estavam voltadas prioritariamente para atender a padres e alunos dos colégios.

Entretanto, estavam franqueadas a usuários externos, principalmente personalidades locais. A do Colégio da Bahia, por exemplo, era freqüentada pelo escritor português Francisco Manuel de Melo, que a tornou seu "refúgio intelectual" (LEITE, 2004, t. V, p. 219). Também na Bahia parece ter havido uma sala de consultas reservada ao público (t. II, p. 390) A livraria chegou a intitular-se pública. Um livro do seu acervo, localizado na Biblioteca do Porto em Portugal, contém a seguinte notação na folha de rosto: Liur. Publ. Do Coll. Da Bahia (LEITE, 2004, t. II, p. 390, n. 19). Também a livraria do Colégio do Rio estava aberta ao público. Intitulava-se Publica Collegii Bibiotheca (LEITE, 2004, t. VI, p. 425). Serafim Leite a considera a primeira biblioteca pública do Rio, baseandose, para tanto, no fato de ter encontrado no Palácio São Joaquim, pertencente à Mitra Arquiepiscopal do Rio de Janeiro, livros em cujo frontispício encontra-se escrito à mão: "Pertence à Livraria Pública do Collo do Rio de Janro" (LEITE, 2004, t. VI, p. 425, n. 50 e 426).

O empréstimo era adotado, embora de forma controlada para evitar a dispersão das obras. A prática chegou a ser proibida em determinado momento. O visitador Inácio de Azevedo, que chegou em 1556,

8 A existência de tipografias nos colégios jesuítas é uma questão em aberto. Rubens Borba de Moraes aventa a possibilidade de que elas poderiam ter existido em decorrência natural das atividades que os padres exerciam. Informa que perguntou ao padre Serafim Leite se teria encontrado alguma documentação sobre o assunto, e o mesmo respondeu que não. Entretanto, o autor, embora de maneira vaga, se refere à tipografia do Colégio do Rio. Cf. MORAES, R. B. Tentativas de estabelecimento de tipografias. In: Livros e bibliotecas no Brasil colonial. Brasília: Briquet de Lemos, 2006. p. 68. 
recomendou que não fosse realizado (LEITE, 2004, t. II, p. 390). A orientação foi modificada pelo visitador seguinte, que sugeriu que não fossem emprestados os títulos únicos e que se abrisse exceção para as pessoas qualificadas como o prelado ou outras de nível elevado (t. II, p. 390). Assim, foi permitido o empréstimo "principalmente aos mais entendidos, [de] grande quantidade de livros" (LEITE, 2004, t. IV, p. 113). No Colégio do Maranhão, não eram emprestados apenas livros de caráter devocional ou catecismos, mas também outros que tratavam de "coisa do espírito", como relatou Vieira (LEITE, 2004, t. IV, p. 113). Havia também empréstimos às pessoas que exerciam profissões de interesse da população. No Inventário da farmácia do Colégio do Maranhão, há o registro de cinco tomos que estavam na casa do cirurgião Manuel de Sousa, espécie de empréstimo especial (LEITE, 2004, t. IV, p. 113).

Os livros religiosos e edificantes, como vidas de santos e de vultos importantes da Companhia, eram amplamente difundidos. Relata-se o caso de certo Manoel da Cunha, morador de Porto Seguro, na Bahia. Perseguido pelo demônio, viu-se livre das tentações após a leitura da vida de Santo Inácio, que teria sido emprestada pelos padres (LEITE, 2004, t. II, p. 390).

A utilização dos livros estava regulamentada. Um exemplo das normas adotadas pode ser conhecido no regulamento do Seminário de Belém da Cachoeira, na Bahia. Trata-se de um documento composto de três partes com 44 parágrafos. A primeira cuidava dos fins da instituição, gêneros dos estudos, regime econômico e financeiro, e normas gerais de funcionamento. A segunda dizia respeito às atribuições dos mestres e superiores; e a terceira estipulava os horários, estudos, práticas de devoção, recreios e disciplina escolar. Entre as normas dessa terceira parte, intitulada Ordem que se deve guardar no Seminário de Belém, estão estipulados os cuidados que os alunos deveriam ter com os livros. Segundo o parágrafo 5, o aluno "[...] que riscar livro ou parede será castigado" e recomendava: "Tratem os livros com asseio, como convém a meninos bem criados" (LEITE, 2004, t. V, p. 247).

O hábito de leitura também foi incentivado. Para tanto, os padres distribuíam prêmios na forma de livros em datas especiais. Um das festas importantes era a abertura do ano letivo. Ficaram famosas as ocorridas no Colégio de Pernambuco, em Olinda, nos anos de 1573 e 1574. Nessas ocasiões, eram realizadas sessões literárias com declamações e representações teatrais pelos alunos Os mais distinguidos recebiam prêmios em dinheiro ou livros (LEITE, 2004, t. I, p. 163). É possível que essa prática fosse adotada nos demais colégios.

Antes que fossem dispostos para a consulta, os livros passavam por exame. Determinava-se que fossem corrigidos aqueles que contivessem conteúdo "contrário à edificação e bons costumes" (LEITE, 2004, t. II, p. 390). Só depois eram colocados à disposição dos leitores. Havia restrições quanto aos livros "poéticos", fazendo-se distinção entre os escritos em latim e os em "romance", ou seja, em línguas românicas (LEITE, 2004, t. II, p. 390). Com relação aos últimos, havia maior reserva, pois se considerava que os mesmos contribuíam para a criação de devaneios nos 
jovens e eram obstáculo para o estudo do latim, a língua culta da época. (LEITE, 2004, t. II, p. 390). Chegou a haver uma proibição, em determinado momento, do procurador-geral de se declamar sonetos nas festas dos colégios, pois poderia incentivar a leitura de livros profanos. Mesmo textos de determinados autores latinos sofreram restrições. Em 1583, a Congregação Provincial da Bahia determinou expurgos em livros de Plauto, Terêncio, Horácio, Marcial e Ovídio (LEITE, 2004, t. II, p. 390). Tal procedimento seguia a prática usada no Colégio Romano da congregação, onde livros eram "expurgados e adaptados ao ensino da juventude" (LEITE, 2004, t. II, p. 390). No Brasil, os padres tinham, desde 1564, licença do cardeal infante para expurgar textos livros (t. II, p. 390, n.14).

\section{Os bibliotecários}

As livrarias estavam sobre a supervisão de um religioso. Havia também sob sua responsabilidade outros, como os irmãos, que estavam encarregados do funcionamento diário e da limpeza do recinto.

Em decorrência das suas pesquisas, Serafim Leite publicou o levantamento das artes e ofícios exercidos pelos jesuítas no Brasil ${ }^{9}$. Apresenta nomes de nove religiosos que exerceram atividades nas livrarias. Um no século XVII e os demais no XVIII. Um número muito pequeno, considerando que as livrarias existiam em praticamente todas as casas desde o século XVI. Provavelmente outros nomes podem aparecer em novas pesquisas.

São registradas diversas denominações para os nossos primeiros bibliotecários: conservador da biblioteca (bibliothecae custos), prefeito da biblioteca (bibliothecae praefectus, bibliotecário (bibliothecarius), livreiro (bibliopola; libraruis), encadernador (librorum instaurator; bibliopegus), tipógrafo (typographus) e impressor (impressor).

As atividades na biblioteca também poderiam ser exercidas com outras paralelas em um mesmo colégio. Assim foram encontrados religiosos que, além de bibliotecários, eram enfermeiros, mestres de meninos, administradores da olaria e ajudantes do procurador. Ao mudar de colégio, o religioso nem sempre se ocupava da mesma função.

Havia também funcionários externos assalariados para tarefas auxiliares. Assim foi o caso de certo Lourenço, cafuzo, no Colégio do Pará, que, além de livreiro, era alfaiate (LEITE, 2004, t. III, p. 520, n. 7). Foi o precursor dos auxiliares de bibliotecas.

Encontram-se informações sobre dois bibliotecários. O primeiro é o padre Antonio Vieira. Segundo seu próprio testemunho, sempre fora bibliotecário em todos os colégios por onde passava. Foi bibliotecário no Colégio da Bahia (LEITE, 2004, t. V, p. 216), sendo que, antes, esteve no Maranhão e no Pará. Em Portugal passou por Lisboa, Porto e Coimbra. Para a livraria desta cidade mandou fazer estantes por sua própria conta

9 Cf. LEITE, S. Artes e ofícios dos jesuítas no Brasil (1549-1760). Lisboa: Brotéira, 1953. 
(LEITE, 2004, t. V, p. 216). O nome de Vieira, contudo, não consta como bibliotecário no levantamento dos ofícios jesuíticos ${ }^{10}$.

O segundo é o irmão Antonio da Costa, referido em documento de 1694 como "diligente e hábil" (LEITE, 2004, t. V, p. 216) ${ }^{11}$. Exerceu as funções de bibliotecário, encadernador e tipógrafo no Colégio da Bahia. Organizou o catálogo da biblioteca, como já visto.

\section{As livrarias}

A mais importante foi a do Colégio da Bahia. Iniciou-se em 1549, com os livros trazidos pelo Padre Manuel da Nóbrega (LEITE, 2004, t. V, p. 216). Com a reconstrução do Colégio e da Igreja, iniciada em 1624 após a invasão holandesa, passou a ocupar um suntuoso salão, hoje ainda existente, cujo teto pintado é um dos mais belos exemplos da pintura colonial ${ }^{12}$. Em 1694, a biblioteca possuía cerca de 3.000 livros, "de todo o gênero de escritores que se podem desejar e se renova e guarda por um diligente livreiro", que foi o irmão Antonio da Costa, visto acima (LEITE, 2004 , t. V , p. 216). Estima-se que, no fechamento do colégio, chegou a ter cerca de 15.000 volumes (LEITE, 2004, t. V, p. 216). A botica do colégio também possuía livraria própria, espécie de biblioteca especializada.

Também na Bahia, o Seminário de Belém da Cachoeira, que começou a ser construído em 1687 no Recôncavo Baiano, possuía livraria. Foi o primeiro colégio interno do Brasil. Durante seu funcionamento, passaram por ele cerca de 1.500 alunos (LEITE, 2004, t. V, p. 244). A livraria estava em constante aumento, tendo registrado em 1735 a entrada de 70 volumes (LEITE, 2004, t. IV, p. 248, n. 9).

No Maranhão, a principal livraria foi a do Colégio de Nossa da Luz. Quando lá chegou o padre Antonio Vieira, em 1652, que foi o responsável por uma das suas ampliações, encontrou quatro cubículos, um deles já ocupado pela livraria (LEITE, 2004, t. III, p. 485). A ela foram acrescidos os livros de sua propriedade trazidos de Portugal (LEITE, 2004, t. IV, p. 113). Em 1760 o Colégio já estava consideravelmente ampliado e a livraria continha 5.000 volumes. Estava situada paralela à igreja, hoje a Catedral Metropolitana de São Luís, com amplas janelas voltadas para o pátio interno (LEITE, 2004, t. IV, p. 113). Ocupava uma sala com uma

10 A ligação de Vieira com as bibliotecas merece ser mais conhecida. Segundo suas próprias palavras, referindo-se aos seus estudos em Portugal, diz que foi [...] mais morador da livraria que da cela. Conhecia bastante os livros, pois foi [...] sempre bibliotecário em todos os colégios [por onde passou]. Durante as missões diplomáticas realizadas na Holanda, França, Inglaterra e Itália, aproveitou para conhecer as [...] melhores livrarias do mundo [...]. Cf. VIEIRA, Antonio. Obras inéditas. Lisboa: 1858. p. 44.

11 Natural de Lião, França, entrou na ordem na Bahía em 23 de julho de 1677, com 33 anos, e faleceu nessa mesma cidade em 17 de outubro de 1722.

12 A biblioteca possui uma escadaria de acesso cujas paredes laterais são revestidas por painéis de azulejos fabricados sob medida em Lisboa entre 1730 e 1740. As extremidades inferiores e superiores de ambos os lados dos painéis trazem a reprodução de figuras masculinas em tamanho natural que parecem conduzir o visitante a adentrar no recinto da biblioteca. O salão é precedido por um vestíbulo também revestido por três painéis de azulejo com figuras alegóricas que representam a Eloqüência, a Filosofia e a Ótica; igualmente produzidos em Lisboa no mesmo século. O teto do salão é coberto por um painel monumental pintado na primeira metade do século XVIII, de autoria ainda ignorada, cuja figura central é uma alegoria da sabedoria. Cf. VALADARES, C. P. Aspectos da arte religiosa no Brasil. Rio de Janeiro: Odebrecht, 1981. 
grande mesa de consulta no centro e as estantes dispostas ao seu redor LEITE, 2004, (t. IV, p. 113).

Em outras casas dependentes do Colégio do Maranhão existiam livrarias. A Casa dos Exercícios e Religiosa Recreação de Nossa Senhora Madre de Deus, casa de campo dos mestres e estudantes do Colégio, possuía livraria "[...] com estantes a propósito, em que ficaram perto de 1.000 volumes de todas as matérias, quase todos encadernados de novo em pasta" (LEITE, 2004, t. III, p. 602), conforme registra O Inventário de 1760.

São mencionadas ainda as livrarias pertencentes ao Seminário, que dispunham de uma "estante de livros pela maior parte de línguas estranhas" (LEITE, 2004, t. III, p. 487) e outra de pequeno porte pertencente à Fazenda de Anindiba, atual município de Paço do Lumiar (LEITE, 2004, t. III, p. 492). Outras, também pequenas, estavam situadas no Seminário das Aldeias Altas, hoje Caxias, e de Parnaíba (LEITE, 2004, t. IV, p. 113), e na Casa-Colégio de Tapuitapera, atual Alcântara (LEITE, 2004, t. III, p. 513).

No Pará, após o estabelecimento, em 1653, dos jesuítas em Belém, foram iniciadas as obras do Colégio de Santo Alexandre, que passaram por várias etapas. O Catálogo de 1718 já registra a existência da livraria e uma sala de consulta (LEITE, 2004, t. III, p. 519) com 1.263 volumes. Em 1760, segundo o Inventário, a livraria possuía 2000 volumes. Ficava situada no corredor do lado do poente. Dispunha de oficina de encadernação e mobiliário adequado, como já descrito. Estava ornada com uma escultura de Nossa Senhora com o menino nos braços, a Sedes Sapientiae, e uma pintura de São Jerônimo, o tradutor da vulgata (LEITE, 2004, t. III, p. 519).

Outras fundações no Pará também possuíam livros. A Casa-Colégio de Vigia, que começou entre 1732 e 1735, dispunha de uma livraria com 1.010 volumes (LEITE, 2004, t. III, p. 544). Dela, foi conservado o catálogo que se encontra publicado na íntegra (LEITE, 2004, t. IV, p. 160167). A Residência da fazenda de Ibirajuba, possuía pequena livraria. Entre os livros, havia a Crônica do Brasil, de Simão de Vasconcelos (LEITE, 2004, t. III, p. 550). O Seminário de Nossa Senhora das Missões dispunha de "alguns centenares" de livros (LEITE, 2004, t. IV, p. 113).

Em Pernambuco, a livraria do Real Colégio de Olinda, fundado no século XVI e reedificado após a expulsão dos holandeses, "era excelente e não pequena" (LEITE, 2004, t. V, p. 336). O Colégio de Jesus do Recife, inaugurado em 1677, tinha sua livraria instalada em uma sala com oito janelas sobre a sacristia da igreja (LEITE, 2004, t. V, p. 346). Estava sempre em crescimento, por meio de compras e doações, como a registrada em 1717 (LEITE, 2004, t. V, p. 352).

A livraria do Colégio do Rio de Janeiro começou a ser organizada já no século XVI, juntamente com a fundação da casa (LEITE, 2004, t. VI, p. 425). Em 1643, a biblioteca já estava bem provida de livros que chegavam por compra ou doação. Foi restaurada no início do século XVIII, juntamente com o Colégio, e passou a ocupar sala própria com estantes novas, como já descritas. O acervo era renovado com livros que vinham 
anualmente de Portugal e de outros países da Europa (LEITE, 2004, t. VI, p. 425). Em 1734 entraram 92 volumes. Os volumes encontravam-se enfileirados nas estantes ao lado de alguns impressos na própria casa em 1724, para uso privado do colégio e dos padres (LEITE, 2004, t. VI, p. 425). Na sua sala ocorreu, em 1641, a aclamação de D. João IV como rei de Portugal, após a Restauração (LEITE, 2004, t. VI, p. 430). Estava aberta aos estudantes e ao público, como visto.

\section{O conteúdo das livrarias}

Serafim Leite considera que os acervos das bibliotecas jesuíticas eram de boa qualidade e quantidade, conforme as observações que fez acerca de algumas delas. A biblioteca do Colégio do Rio reunia "milhares de obras" (LEITE, 2004, t. VI, p. 425). O Colégio do Recife "era dotado de boa biblioteca" (LEITE, 2004, t. V, p. 352). O do Espírito Santo "possuía uma biblioteca rica e abundante" (LEITE, 2004, t. VI, p. 464). A da Bahia, a maior de todas, possuía livros "de todo o gênero de escritores que se podem desejar e se renova e guarda por um diligente livreiro" (LEITE, 2004 , t. V, p. 216). A do colégio de São Paulo "era rica e abundante" (LEITE, 2004, t. VI, p. 558).

São conhecidos, até o presente, os catálogos de duas livrarias: a do colégio de Vigia, no Pará, e a do Rio de Janeiro. Ambos foram feitos durante o inventário dos bens da Companhia após a expulsão da ordem. Leite acredita que todas foram inventariadas no momento do seqüestro, mas, ou perderam-se todos os inventários, ou ignora-se ainda o seu paradeiro ${ }^{13}$.

O catálogo da casa de Vigia registra 1.010 volumes "que se achavam [na casa] quando o padre Caetano Xavier, então superior, foi preso". (LEITE, 2004, t. IV, p. 167). Predominam livros de cunho religioso nos campos de teologia, direito, moral, ascética, escriturística, apologética, liturgia e filosofia. No sermoniário, registra-se obras da oratória sacra da época. Aparecem obras poéticas de Homero em grego e em latim, obras de Virgílio, Horácio, Marcial, Ovídio, Terêncio e Cícero. A história e a geografia estavam representadas com diversas obras. A engenharia, medicina e matemática se faziam presentes com alguns títulos. De autores portugueses como Camões e Vieira, encontravam-se as obras completas. A livraria, "imersa como um foco de luz nas selvas coloniais do Brasil, possuía um pouco de tudo", conclui Leite (LEITE, 2004, t. IV, p. 167).

A livraria do colégio do Rio de Janeiro foi inventariada 15 anos após a saída dos jesuítas, quando muitos livros já estavam destruídos e outros nas mãos de terceiros. Possuía milhares de obras de ciências sacras e profanas. Obras de Aristóteles, Platão, Plínio e Virgílio e os famosos "Conimbricenses"14. As ciências físicas e naturais estavam presentes com

13 LEITE, S. Uma biblioteca portuguesa no Brasil dos tempos colônias. Brasília, v. 1, 1942. p. 257.

14 Trata-se dos compêndios do Cursus Coninbricencis, criados pelos jesuítas no Colégio das Artes de Coimbra e voltados para o estudo de Aristóteles. 
obras de Isaac Newton e Boscovich ${ }^{15}$. De autores portugueses, havia títulos em praticamente todos os campos. Completavam as obras relacionadas com as matérias ensinadas no Colégio nas áreas de humanidades, matemática, filosofia, teologia, e uma boa coleção de história e direito civil (LEITE, 2004, t. VI, p. 425) ${ }^{16}$.

Pelos exames dos dois catálogos, pode-se inferir o conteúdo das livrarias em todos os colégios do Brasil. Eram livrarias especializadas. Seus acervos cobriam em primeiro lugar as disciplinas ministradas nos colégios. Ao lado, havia também, em todas, boas coleções de cunho religioso que abrangiam teologia moral, direito canônico e hagiologia. Esses livros eram essenciais para auxiliar os padres nas atividades religiosas.

\section{Os destinos das livrarias}

Com a saída dos jesuítas, todos seus bens imóveis e móveis foram confiscados e tiveram destinos diversos. No que tange às bibliotecas e seus livros, veio a ocorrer um completo desmantelamento e desaparecimento dos acervos construídos ao longo de 200 anos. A história desse período, uma parte da história da destruição das bibliotecas no mundo, é ainda desconhecida.

Qual foi o destino de tantos livros? Serafim Leite apresenta pistas do que teria ocorrido. Hasta pública, remessa para Lisboa, doação a autoridades diocesanas de cada local - e até a particulares, parecem ter sido os destinos finais dos acervos. Acrescente-se ainda que muitos, abandonados durante largo período em condições inadequadas, foram parcial ou totalmente destruídos, pela ação de insetos e fungos, ou objeto de roubo.

As livrarias do Pará totalizavam cerca de 4.000 volumes no momento da saída dos padres (LEITE, 2004, t. IV, p. 113). Em 1760, foi decidido que as duplicatas existentes nesse total deveriam ser remetidas para Lisboa para venda (LEITE, 2004, t. IV, p. 113). O restante seria reunido para constituir o fundo da biblioteca pública da cidade (LEITE, 2004 , t. IV, p. 113). Tal não aconteceu e os livros permaneceram no Colégio (LEITE, 2004, t. IV, p. 113). Posteriormente, os livros dos Colégios de Santo Alexandre e da Vigia, por Carta Régia de 11 de junho de 1761, foram doados a um Colégio de Nobres, que nunca chegou a funcionar (LEITE, 2004, t. IV, p. 113).

15 Trata-se do matemático, astrônomo e físico jesuíta nascido em Dubrovick em 1711. Viveu na Inglaterra, França e finalmente na Itália, onde ficou conhecido como Ruggero Giuseppe Boscovich. Faleceu em Milão em 1787. A obra de sua autoria que consta do Auto do inventário deve ser Elementos de matemática, publicada em 1752. Está grafada "Lementos de Boscoviche sete t.s a cem reis e setesentos reis". A obra de Newton, grafado Neuton, não está indicada.

16 O inventário foi comentado por Rubens Borba de Moraes, que nota as incongruências contidas e a maneira vaga como considerável número de obras foi arrolada, o que dificulta a identificação das mesmas.

Cf. MORAES, Rubens Borba de. Livros e bibliotecas no período colonial. Brasília: Briquet de Lemos, 2006, p. 114, nota 13. Igual observação foi feita na nota introdutória da publicação do Auto de inventário na Revista do Instituto Histórico e Geográfico Brasileiro. Comenta a ortografia "incrível" do escrivão, sua ignorância de nomes estrangeiros e até de autores portugueses, o que faz supor que os títulos poderiam ter sido mal ditados pelos livreiros avaliadores ou por auxiliares sem maior atenção. Cf. Revista do Instituto Histórico e Geográfico Brasileiro, v 301, p. 213, 1973. 
Por volta desse mesmo período, parte do acervo foi remetida para Portugal. Dom João de São José e Queirós, beneditino e quarto bispo do Pará no período de 1760 a 1763, enviou "dez caixões com os ricos livros dos jesuítas aos seus confrades de Lisboa" (LEITE, 2004, t. IV, p. 113). ${ }^{17}$ Por fim, a Carta Régia de 11 de junho de 1790 determinou que o Colégio de Santo Alexandre e seus bens fossem destinados à Mitra (LEITE, 2004, t. III, p. 519) Teriam sido os livros incluídos?

Os livros do Maranhão foram entregues pela Carta Régia de 11 de junho de 1761 ao bispo diocesano. Entretanto, todas essas obras foram dispersas, conforme observação de César Marques, autor do Dicionário do Maranhão, citado por Leite (LEITE, 2004, t. IV, p. 113).

Essa situação pode ser confirmada no relatório intitulado Exames nos arquivos dos mosteiros e das repartições públicas para a coleção de documentos históricos relativos ao Maranhão, datado de 1851, de autoria do poeta Antonio Gonçalves Dias, que oferece informações sobre o estado das bibliotecas do Maranhão em meados do século passado. Quanto aos livros dos jesuítas, que foram confiados ao bispo diocesano, o relatório cita e anexa cópia, a informação prestada ao presidente da província, em 1831, pelo bibliotecário público padre Antônio Bernardo da Encarnação e Silva, que investigou "o montão de livros arruinados" que pertenceram aos padres. Tendo em vista o que constatou, o bibliotecário afirma que não pode "deixar de lastimar que, entre mil volumes, pouco mais ou menos que [...] existem apesar dos grandes extravios, se não encontre uma única obra completa, que mereça ser aproveitada, visto o destroço total, em que se acham, não só ocasionado pelo cupim e traça, como pelo abandono, em que os mesmos livros sempre se conservaram, resultando de tudo, que sendo a sobredita livraria em seu princípio de valor inestimável [...] hoje desgraçadamente apenas pode prestar o que resta para alimento das chamas"18. Ou seja, os volumes estavam em estado adiantado de deterioração. Vinte anos depois, quando realizou o seu trabalho, Gonçalves Dias nada mais encontrou e concluiu que a destruição foi completa (LEITE, 2004, t. IV, p. 113) ${ }^{19}$.

O relato do bibliotecário público do Maranhão e as observações de Gonçalves Dias podem retratar o que poderia ter acontecido com os acervos jesuíticos em outros locais do Brasil.

17 Serafim Leite informa que, durante sua pesquisa de livros pertencentes aos jesuítas no Brasil em bibliotecas de Portugal, localizou alguns livros do Colégio do Pará. Cita a obra Arte da Língua Brasílica de autoria de Luiz Figueira, com a notação $\mathrm{Co}^{\circ}{ }^{\circ}$ do Pará. Afirmava tratar-se do único exemplar da primeira edição de 1621. Borba de Moraes, contudo, na sua Bibliographia brasiliana, informa a existência de dois exemplares conhecidos. Um pertencente à Biblioteca Nacional de Lisboa, com a indicação de propriedade do Colégio do Pará, e outro, à Biblioteca Nacional do Rio de Janeiro. Uma busca no sítio da Biblioteca Nacional de Lisboa www.bn.pt/ confirma a existência da obra e informa que a mesma pertencia à Companhia de Jesus no Pará. Foi certamente o exemplar visto por Serafim Leite. O exemplar da Biblioteca Nacional do Rio de Janeiro foi localizado na busca no sitio da mesma: www.bn.br.

18 Cf. Ofício do padre Antonio Bernardo a Encarnação e Silva. R. Bibliotecon. Brasília. v. 1, n. 2, lul./dez. 1973. p. 249-250.

19 Cf. também DIAS, A. G. Exames nos arquivos dos mosteiros e das repartições públicas para a coleção de documentos históricos relativos ao Maranhão. R. Bibliotecon. Brasília. V. 1, n. 2, lul./dez. 1973. p. 241-250. 
Quando da saída dos jesuítas, Serafim Leite estima em 15.000 os livros da livraria do Colégio da Bahia (LEITE, 2004, t. V, p. 216). O que teria acontecido com as coleções?

No início, algumas ordens religiosas mostraram interesse em adquirir as melhores obras, o que foi negado pelas autoridades, sendo nomeado um depositário para o acervo (LEITE, 2004, t. V, p. 216). Chegando o novo arcebispo, D. Joaquim Borges de Figueiroa solicitou os livros, pois pretendia reiniciar os estudos interrompidos com a saída dos jesuítas. Esse desejo parece não ter se realizado, "porque os tempos não iam favoráveis, depois a saída dos padres [os jesuítas], à cultura das letras", avalia Leite (LEITE, 2004, t. V, p. 216).

O estado da biblioteca nos tempos que se seguiram pode ser conhecido por meio do relato de Luiz dos Santos Vilhena nas suas Cartas de Vilhena: abandono, furtos e pose por particulares. Assim relata:

He penna que a sacristia que foi dos Jesuitas se tenha perdido e vá cada vez mais se arruinando, por ser huma das magnificas pessas daquele genero, bem como a caza da Livraria, cujos livros bons e muitos tem sido furtados e outros vendidos por quem os furtara por vilissimos preços a Boticarios e Tendeiros para embrulhar adubos e unguentos, podendo ter-se com modica despesa conservado, ainda que fora para nelles se consultar muitas couzas, para que aqui não apparecem livros; outros porem consta terem sahido para armar estantes de particulares, sem que hoje exista nada delles20.

O que sobrou da livraria veio a constituir o fundo da Biblioteca Pública da Bahia, aberta em 13 de maio de 1811, que contou ainda com doação de particulares (LEITE, 2004, t. V, p. 217). Em 1817, somava 7.000 volumes, ou seja, cerca da metade dos 15.000 exemplares do acervo original avaliado por Leite. Nessa época, reinstalada no primitivo salão do Colégio, recebeu a visita do príncipe Maximiliano, que lamentou a dispersão dos livros da antiga livraria: "Que grande perda resultou de não ter tido bastante cuidado com os papéis dessa Ordem Religiosa: foram na sua maior parte dispersados" (LEITE, 2004, t. V, p. 217) ${ }^{21}$.

20 Luís dos Santos Vilhena (1744-1814) nasceu em Portugal e em 1787 foi nomeado professor de língua grega em Salvador, onde faleceu em 1814. Exerceu atividades no chamado ensino régio, criado para substituir os colégios jesuíticos, únicos existentes até então. Nas suas observações, além de se conhecer o estado em que se encontrava a biblioteca do Colégio da Bahia, pode-se sentir a falta que os livros estavam fazendo para apoiar as atividades docentes. As Cartas de Vilhena reúnem cartas redigidas pelo autor endereçadas a amigos fictícios. Começaram a ser redigidas em 1798 e foram concluídas em 1802.

21 A história da fundação da Biblioteca Pública da Bahia consta em um dos capítulos de Livros e bibliotecas no Brasil Colonial, de Rubens Borba de Moraes. O autor apresenta informações sobre o nascimento da biblioteca que divergem das apresentadas por Leite. Não são referidos os livros da Livraria do Colégio da Bahia, que serviram de fundo para a coleção inicial da Biblioteca. Cita o testemunho de Tollenare, que a visitou em 1817, quando encontrou cerca de 4.000 volumes. Analisa também os catálogos da biblioteca, um impresso e outro manuscrito, cujo número do acervo também diverge das informações de Leite. Cf. MORAES, R. B. A fundação da Biblioteca Pública da Bahia. In: Livros e bibliotecas no Brasil Colonial. 
No Espírito Santo, a "boa livraria" (LEITE, 2004, t. VI, p. 463) com que contava o colégio teve seus livros dispersados entre várias pessoas. Recolhidos em 1771, foram remetidos para Lisboa, como registrou SaintHilaire no relato da sua passagem pela província, em 1818, citado por Leite (LEITE, 2004, t. VI, p. 463).

O caso do Colégio do Rio de Janeiro é o mais documentado. Os livros, que chegavam a milhares em 1760 (LEITE, 2004, t. VI, p. 425), ficaram abandonados em uma dependência do mesmo colégio durante os 15 anos que se seguiram à saída dos jesuítas. ${ }^{22}$ Muitos "andavam por fora" (LEITE, 2004, t. VI, p. 426), isto é, estavam na mão de terceiros. A livraria continuava a servir aos mestres e às escolas que se instalaram na cidade após a saída dos jesuítas, considerou Leite (LEITE, 2004, t. VI, p. 426).

Em face do "mau estado de ruína" (LEITE, 2004, t. VI, p. 425) em que se achavam os livros, o vice-rei marquês do Lavradio (1729-1790) determinou, por meio de Portaria, que se fizessem três lotes: "os que forem de doutrina e disciplina eclesiástica" deveriam ser encaminhados ao Prelado do Rio; "os que forem proibidos" enviados a Lisboa para o Juízo da Inconfidência "e o resto que ficar distribuído pelas casas de alguns ministros e letrados que se julgar serem capazes não só de dar conta deles, mas de the darem o melhor trato". ${ }^{23}$

Em 22 de julho de 1775 foram iniciados o inventário e a avaliação das obras para o cumprimento das determinações do vice-rei. Reuniramse para tanto o desembargador Manuel de Albuquerque e Melo, o escrivão Antonio Machado Freire e "dous mestres livreiros da melhor nota e ciência" existentes no Rio na época, Pedro da Silva Tôrres e Manuel Francisco Gomes, que, sob juramento, avaliaram os títulos inventariados (LEITE, 2004, t. VI, p. 426).

O inventário arrolou "quatro mil setecentos e um livros" aproveitáveis que somaram "a quantia de hum conto, cento e cinqüenta e dois mil, quinhentos e novena reis salvo erro (1.125\$590rs)" (LEITE, 2004, t. VI, p. 426). Um total de 734 "livros de vários autores de várias matérias" foi considerado sem valor, tendo em vista "que de nada prestam, por destruídos, podres e arruinados" (LEITE, 2004, t. VI, p. 426). O documento ainda registra outros livros em adiantado estado de deterioração que não foram avaliados por se acharem "todos despedaçados e comidos do bicho" (LEITE, 2004, t. VI, p. 426) ${ }^{24}$.

2. ed. Brasília: Briquet de Lemos, 2006. p. 152- 170. Em 1912, a biblioteca que se achava instalada na ala térrea dos fundos do palácio do governo foi incendiada por um bombardeio que atingiu o edifício. $O$ desastre ocorreu durante os conflitos políticos sofridos pelo estado em decorrência da renúncia do governador João Ferreira de Araújo Pinho (1908-11). Seu acervo ficou reduzido a 300 ou 400 volumes.

22 O ocorrido com a Livraria do Colégio do Rio de Janeiro é o caso mais conhecido e documentado. Foi preservado no arquivo do Instituto Histórico e Geográfico do Brasil o manuscrito Auto de inventário e avaliação dos livros achados no Colégio dos jesuítas do Rio de Janeiro e seqüestrados em 1775. (Arquivo do I.H.G.B. - L.58-D. 8). Foi publicado na Revista do Instituto Histórico e Geográfico Brasileiro, v 301, p. 212-259, 1973.

23 A Portaria com as determinações foi datada de 14 de julho e o Cumpra-se de 17 de julho de 1775.

24 Rubens Borba de Moraes comenta com propriedade o documento do inventário e analisa os principais títulos que foram arrolados. Cf. MORAES, R. B. As bibliotecas dos jesuítas. In: no Brasil Colonial. 2. ed. Brasília: Briquet de Lemos, 2006. p. 10- 13. 
Os livros destinados ao Prelado do Rio foram entregues ao Procurador da Mitra, na qualidade de "depositário legal" no dia 28 de agosto de 1777 (LEITE, 2004, t. VI, p. 426), dois anos depois da realização do inventário. Alguns deles foram localizados pelo autor no Palácio de São Joaquim, do arcebispado do Rio de Janeiro.

Serafim Leite lamenta que "bastaram 15 anos para a ruína da famosa biblioteca do Colégio [do Rio de Janeiro]. Considera que ela seria hoje uma das maiores riquezas culturais da América, se não houvesse solução de continuidade" (LEITE, 2004, t. VI, p. 426).

\section{Conclusões}

O Brasil contou, durante cerca de duzentos anos, com um considerável acervo de livros, à disposição de interessados, nas livrarias jesuíticas. As informações contidas na obra de Serafim Leite, embora dando destaque às mais importantes, oferecem uma visão de como poderia ter sido o seu funcionamento em todo o país. A Companhia de Jesus tinha as suas ações orientadas pelo método intitulado Ratio Studiorium, que determinava procedimentos uniformes em todos os colégios da ordem, inclusive quanto a livros, bibliotecas e práticas de leitura ${ }^{25}$.

O desmantelamento dos acervos, ocorrido após a saída dos jesuítas, privou o país de um importante patrimônio cultural. Torna-se necessário que se conheça melhor a história desse período e o destino de tantos livros, como subsídio para a história das idéias e da formação do conhecimento no Brasil.

A criação de livrarias semelhantes também ocorreu em outros países da América Latina, onde os jesuítas se estabeleceram e de onde também foram expulsos. Entretanto, a dispersão dos acervos não ocorreu tal como no Brasil. Em alguns desses países, onde a imprensa já havia sido introduzida e universidades foram fundadas, existiram instituições que foram capazes de absorver os livros. Algumas bibliotecas nacionais tiveram como núcleo original os livros dos jesuítas, como no Peru, Colômbia e Argentina. Neste último país, está em desenvolvimento um projeto para a reconstituição do fundo bibliográfico da Companhia de Jesus no país ${ }^{26}$. O conhecimento desses acervos poderá oferecer uma idéia das coleções que existiram no Brasil.

O conhecimento sobre a história das bibliotecas brasileiras no período colonial, principalmente na época dos jesuítas, deve ser ampliado, a partir das informações de Serafim Leite. Para tanto, será necessário revisitar os arquivos, hoje seguramente em melhores condições de consulta do que na época do autor, e ampliar as pesquisas.

25 Cf. O Método Pedagógico dos Jesuítas : "Ratio Studiorum". Disponível em < http://www.histedbr.fae.unicamp.br/navegando/fontes escritas/1 Jesuitico/ratio\%20studiorum .htm> Acesso em 22 maio 2007.

26 Cf. http://www.bcnbib.gov.ar/libraria/libraria5a.htm. Acesso em 22 maio 2007 


\section{Referencias}

AUTO de inventário e avaliação dos livros achados no Colégio dos jesuítas do Rio de Janeiro e seqüestrados em 1775. Revista do Instituto Histórico e Geográfico Brasileiro, v. 301, p. 212-259, 1973.

LEITE, S. Artes e ofícios dos jesuítas no Brasil (1549-1760). Lisboa: Brotéira, 1953.


$\overline{2004.10} \mathrm{v}$.

- História da Companhia de Jesus no Brasil. São Paulo: Loyola,

MORAES, R. B. Livros e bibliotecas no Brasil colonial. 2. ed. Brasília: Briquet de Lemos, 2006.

VALADARES, C. P. Aspectos da arte religiosa no Brasil. Rio de Janeiro: Odebrecht, 1981.

VIEIRA, A. Obras inéditas. Lisboa: [s.n.], 1858.

DIAS, A. G. Exame nos arquivos dos mosteiros e das repartições públicas para a coleção de documentos históricos relativos ao maranhão (1851). $R$. Bibliotecon. Brasília. v. 1, n. 2, p. 241- 250, jul./dez. 1973.

HISTEDBR - Grupo de Estudos e Pesquisas História, Sociedade e Educação no Brasil.O Método Pedagógico dos Jesuítas. O "Ratio Studiorum". Organização e Plano de Estudos da Companhia de Jesus.Regras do Provincial. Disponível em: <http://www.histedbr.fae.unicamp.br/navegando/fontes_escritas/1_Jesuit ico/ratio\%20studiorum.htm> Acesso em: 22 maio 2007. 